consolidating power, in a system rife with corruption. Meanwhile, an increasingly vocal populace complains of rich officials, environmental problems and food safety.

The government wants to stay in charge of efforts to deal with problems and maintain its goal of stability. It is not alone in such efforts. And it is not alone in setting its sights on what it sees as a possible source of dissent and social strife: non-governmental organizations (NGOs). Russia and India in recent months have already set out worrying plans to stifle such operations. Now China is following.

In China, domestic NGOs are, for the most part, governmentorganized bodies, and so are still under government influence. But foreign NGOs are a concern to the government, and a potential destabilizing force, especially when they try to spread 'Western values'.

Last year, the government surveyed foreign NGOs operating in China and counted about 1,000 permanent operations; when short-term projects are included, NGOs in China number up to 6,000. The government estimates that these groups pour hundreds of millions of dollars into some 20 areas, including health, environmental protection and education. To Chinese officials, these are alarmingly high numbers.

China feels that its grip on these organizations has been too loose. Accordingly, over the past month it has sought comments on a new draft law - the Non-Mainland Non-Governmental Organizations Management Law - that will tighten restrictions on NGOs.

The move may not be a surprise, given the political mood. But the proposed scope of the law is broader than many people expected, and is causing alarm. Its definition of an NGO is so broad - all activities of "not-for-profit, non-governmental social organizations" - that, according to Jia Xijin, a specialist on NGOs in China at Tsinghua University, it covers all organized activities between Chinese nationals and foreigners. Many people, citizens and visitors alike, probably have no idea that the law will apply to them.

The new rules would require individuals or institutions wishing to carry out activities in China to get a sponsor, such as a ministry or other agency of local government. Then they must apply for permission - not to the civil-affairs ministry, as in the existing system, but to the public-security bureau.

What will happen when the public-security bureaus, which are accustomed to operating with a police mindset, start sizing up applications for scientific collaborations? At the very least, the result would be undue, and potentially forbidding, restrictions and red tape. It would probably, for instance, discourage studies of environmental problems that regional governments are not ready to admit to. At the very worst, it would allow the persecution of institutions or of individuals from blacklisted institutions.

Could a political demonstration at a university overseas mean that researchers from that university would no longer be welcome

"Overseas
institutions
have already
expressed
concern."
in China? What if an individual had some other political connection that made officials uncomfortable?

The proposed law is not explicit in how it should be applied to specific collaborations or specific research projects. Those associated with universities or scientific societies in China fear that the decisions will be deferred to officials with little experience of science. What happens when these officials come across a project they do not fully understand? Will they want to take a chance on it? Most probably, observers fear, they would rather just reject it or, more likely, sit on it - and make things easy for themselves.

Overseas institutions have already expressed concern. One response to the Chinese consultation came from Harvard University in Cambridge, Massachusetts, which said that "universities should not be treated as non-governmental organizations and should not be subject to its provisions which, if implemented, could inadvertently make future transnational faculty and student collaborations more difficult, and therefore less frequent".

In an e-mail to Nature, a Harvard spokesperson put it diplomatically: "We would have concern with any law that might inhibit the future ability of faculty and students to work together on common areas of interest by creating new, undue burdens."

Jia says that second- or third-tier universities, and especially local or private universities, are likely to suffer. Whereas prominent governmentaffiliated universities such as Tsinghua or Peking universities, both in Beijing, would probably be accredited as authorized hosts for foreign NGOs that want to carry out temporary activities in China, smaller and less-well-connected universities are unlikely to get such approval.

Both science and China have benefited from the emphasis that the Chinese government has placed in recent years on research as a driver of growth and development. International links are a key component of that. To weaken such networks could do more than cut useful ties. It could undermine the stability that they help to bring.

\section{Tough targets}

\section{Concrete goals set out by the G7 nations lay the groundwork for a climate accord.}

\section{$\mathrm{T}$} he Group of 7 (G7) leading industrialized nations this week called for global greenhouse-gas emissions to be reduced by around $70 \%$ by 2050 , and for the world economy to be decarbonized by the end of the twenty-first century. These twin goals were issued in a communiqué at the conclusion of the group's meeting at Schloss Elmau in Krün, Germany, on 8 June, alongside a suite of promises to help developing nations to provide their citizens with clean energy, jobs, financial security and food.

To the credit of German Chancellor Angela Merkel, leader of the host nation, the commitments surpass all of the G7's previous promises. Most notably, the group has formally acknowledged - and quantified - the scale of the industrial renaissance that will be required to keep global average temperature increase to less than $2^{\circ} \mathrm{C}$ above pre-industrial levels. It has provided concrete and measurable targets that should help to make clear where precious capital and human resources should be invested - not just for other governments, but also for businesses. It should also make clear where resources should not be expended. The G7 nations renewed their pledge to end "inefficient" fossil-fuel subsidies.

The nations also reaffirmed a commitment, made in Copenhagen in 2009 , to increase climate aid for developing countries to US $\$ 100$ billion per year by 2020 , including both public and private financing. The communiqué calls for an expansion of renewable energy in developing countries, and further work to help the most vulnerable countries to prepare for climate change. In particular, the G7 pledged to ensure that 400 million people in developing nations have access to climate-risk insurance, to mitigate the effects of disasters such as droughts and storms.

The timing is good. Nations are wrapping up the latest round of climate talks in Bonn this week, with the aim of advancing a climate agreement to be signed in Paris later this year. Policy-makers have their work cut out if they are to sign a meaningful accord, and the G7 meeting represents a small step in the right direction.

But the world is still waiting for action that will give these targets credibility. Countries should adopt the G7 communiqués emissions targets and look for ways to expand climate-related investment in the developing world, where emissions are poised to rise quickly if no $\rightarrow$ NATURE.COM To comment online, click on Editorials at: go.nature.com/xhunqv intervention is made. The communique rightly points out that engagement by the private sector will be crucial to meeting these goals, but it is up to policy-makers to lay down the rules of the road. 